Proceeding

Oopen Access

D) CrossMark

\title{
Broad spectrum viral molecular drug
}

\begin{abstract}
When Virus first enters the human body or human blood stream the virus start circulates throughout the body. The protective surface of virus is study with particular protein called receptor and lipid membrane envelop inside the capsid that contain a genetic material and viral enzyme. Protein on the virus is only able to bind with a cell surface called cell receptor. From the given Diagram viruses Receptor attached with Lipid envelops. The discovery of structure of the any viruses mainly lipase has made the identification of its inhibitors. Lipase which breaks down lipid envelope of virus which in return stops its replication and outbreak.
\end{abstract}

Volume 8 Issue 6 - 2021

\author{
Umair Masood \\ Gen-CEST biotech company, Pakistan
}

Correspondence: Umair Masood, Gen-CEST biotech company, Pakistan, Tel +923105423 I23,

Email umairawan0505@gmail.com

Received: December 18, 2021 | Published: December 29,
2021

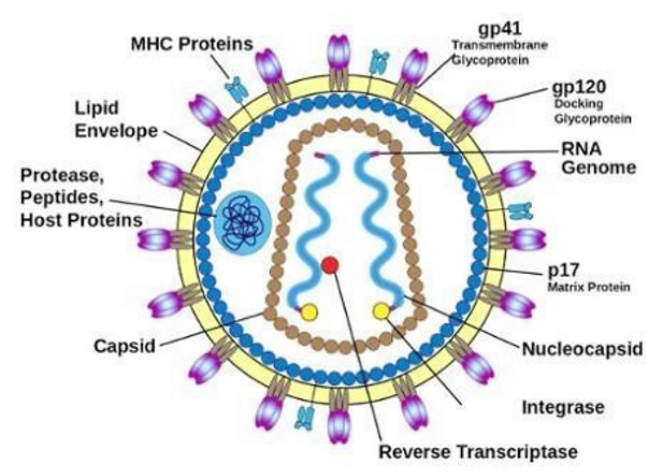

Structure of an HIV-1 virion

https://smhs.gwu.edu/lynch-lab/research-interests

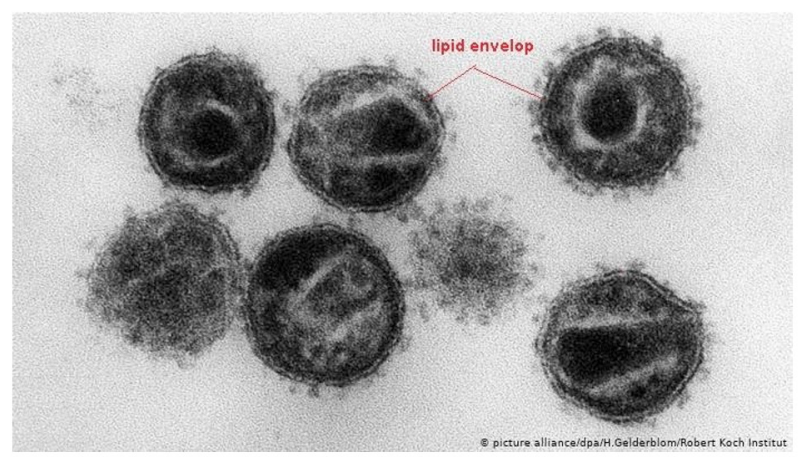

https://www.dw.com/en/hiv-drugs-stop-sexual-transmission-ofaids-virus-say-doctors/a-48588767

\section{Resource requirement for experiment}

I. Centrifuge machine

II. Incubator

III. Lipase enzyme with all reagents

IV. Micropipette

V. Dead strain of virus

VI. Centrifuge tubes

VII. Micro centrifuge tube sspectrophotometer.

\section{Advantages of lipase enzyme}

I. Easily available

II. Cost affective

III. Control pandemic situation

IV. Easily synthesized

V. Fast viral destruction Inhibitor.

\section{Result}

Preliminary analytical characterization of an easy, fast, and costeffective spectrophotometric technique for determination of lipase activity is provided on this work. It is based on the spectrophotometric monitoring of the lipolysis of broad spectrum of viruses.
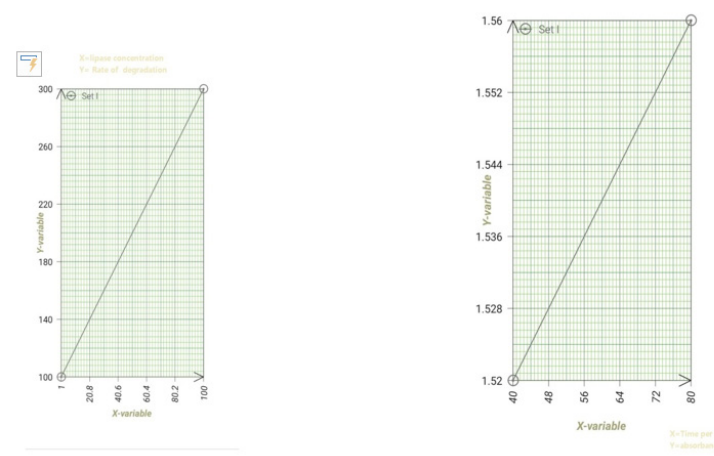

\section{Acknowledgments}

None.

\section{Conflicts of interest}

There are no financial conflicts of interest.

\section{Funding \\ None.}

\section{References}

1. Wu KJ. There are more viruses than stars in the universe. Why do only some infect us? - More than a quadrillion quadrillion individual viruses exist on Earth, but most are not poised to hop into humans. Can we find the ones that are? 2020. 
2. Whitley RJ, Roizman B. Herpes simplex virus infections. Lancet. 2001;357(9267):1513-1518.

3. Krasner Robert. The microbial challenge:a public health perspective Burlington, Mass:Jones \& Bartlett Learning. 2014.

4. Shors T. Understanding Viruses. Jones and Bartlett Publishers. 2017.

5. Mainly Chapter 33 (Disease summaries). In:Fisher B, Harvey RP, Champe P, editors. Lippincott's Illustrated Reviews:Microbiology. Lippincott's Illustrated Reviews Series. Hagerstwon, MD:Lippincott Williams \& Wilkins. 2007. p. 367-392.
6. Coleman JR, Papamichail D, Skiena S, et al. Virus attenuation by genomescale changes in codon pair bias. Science. 2008;320(5884):1784-1787.

7. Expanded Practice Standards. Iowa Administrative Code. 2019.

8. Melief CJ, van Hall T, Arens R, et al. Therapeutic cancer vaccines. The Journal of Clinical Investigation. 2015;125 (9):3401-3412.

9. Vaccine product approval process. U.S. Food and Drug Administration(FDA). 2020

10. Melief CJ, van Hall T, Arens R, et al. Therapeutic cancer vaccines. The Journal of Clinical Investigation. 2015;125(9):3401-3412. 